\title{
Paliperidone Metabolic Effects in Children and Adolescents: A Case Report
}

\author{
Çocuklarda ve Ergenlerde Paliperidonun Metabolik Etkileri: Bir Olgu \\ Sunumu
}

Meltem İnci Kefal' ${ }^{1}$ Hasan Kandemir², Şermin Yalın Sapmaz², Masum Öztürk', Yekta Özkan1, Özge Gözaçanlar Özkan 1

${ }^{1}$ Dr., ${ }^{2}$ Doç. Dr., ${ }^{3}$ Yard. Doç. Dr., Manisa Celal Bayar Üniversitesi Tıp Fakültesi Çocuk ve Ergen Ruh Sağlığı ve Hastalıkları A.D., Manisa

\begin{abstract}
SUMMARY
The use of atypical antipsychotics in children and adolescents has increased in recent years. A 16-year-old male patient reported that he had used paliperidone for 3 years and had gained weight during this period. Various laboratory tests were performed when the patient started treatment in our clinic. It is evident from the test result that 3-year use of paliperidone dramatically increased fasting blood sugar, total cholesterol, low-density lipoprotein, triglycerides and prolactin levels in the patient. The metabolic parameters of the patient decreased into the normal range once the medication was stopped. Thus, paliperidone should be used carefully based on the side effects for patients under 18 years of age.
\end{abstract}

Key Words: Paliperidone, Metabolic Syndrome, Atypical antipsychotic, Child and adolescent

(Turkish J Clin Psych 2017;20:332-333)

DOI: $10.5505 / \mathrm{kpd} .2017 .70288$

\section{To the Editor}

The use of atypical antipsychotics in children and adolescents has increased in recent years. Almandil and Wong (1) emphasised the increasing concern regarding the appropriate use of atypical antipsychotics, as these drugs are likely to cause metabolic abnormalities, such as weight gain, obesity, hyperglycaemia and changes in blood lipid levels. One of the atypical antipsychotics, paliperidone, is the major active metabolite of risperidone (2). The main aim of this study is to present the use of paliperidone and its side effects in the treatment of adolescent patient with mental retardation and behavioural disorder.

\section{ÖZET}

Son yıllarda atipik antipsikotiklerin çocuklar ve ergenlerde kullanımı artmıştır. 16 yaşındaki erkek hasta, paliperidonu 3 yıl kullandığını ve bu dönemde kilo aldığını bildirmiştir. Kliniğimizde hastaya tedavi başlanmasıyla çeşitli laboratuvar testleri yapıldı. Test sonucuna göre paliperidonun 3 yıllık kullanımının hastada açlık kan şekeri, total kolesterol, düşük yoğunluklu lipoprotein, trigliserid ve prolaktin düzeylerini önemli ölçüde artırdığı açıktır. İlaç kesildikten sonra hastanın metabolik parametreleri normal aralığa düştü. Bu nedenle, paliperidon, 18 yaşın altındaki hastalar için yan etkilere dayalı olarak dikkatle kullanılmalıdır.

Anahtar Kelimeler: Paliperidon, Metabolik Sendrom, Atipik antipsikotik, Çocuk ve ergen

\section{Case Report}

A 16-year-old male patient, who received medical treatment for a behavioural disorder at an outpatient clinic, consulted at our polyclinic with complaints such as arguments with his parents, punching doors and windows, irritability and fighting with friends at school. The patient reported that he had used paliperidone (Invega) at $6 \mathrm{mg} /$ day for 3 years and had gained weight during this period. In addition, an EEG taken 6 years ago showed epilepsy, and therefore he had used levatiracetam (Keppra) at $500 \mathrm{mg} /$ day for 6 years, but there was no history of attacks. His family history and neurological examination were normal. The patient performed a WISC-R test in our polyclinic and scored 49 points in total intelligence section, indicating a moderate 
Kefal Mi, Kandemir H, Yalın Sapmaz Ş, Öztürk M, Özkan Y, Gözaçanlar Özkan Ö.

Table 1. Laboratory test results

\begin{tabular}{llll}
\hline Measures & $\begin{array}{l}\text { Before starting } \\
\text { paliperidone }\end{array}$ & $\begin{array}{l}\text { Three years after using } \\
\text { paliperidone }\end{array}$ & $\begin{array}{l}\text { One week after stopping } \\
\text { paliperidone }\end{array}$ \\
\hline Fasting blood sugar & 77 & 102 & 87 \\
\hline Total cholesterol & 180 & 228 & 194 \\
\hline Low-density lipoprotein & 117 & 128 & 133 \\
\hline Triglycerides & 160 & 288 & 113 \\
\hline Prolactin & 4.6 & 18.42 & 3.8 \\
\hline
\end{tabular}

intellectual disability. The patient weighed $95 \mathrm{~kg}$ and was $170 \mathrm{~cm}$ tall, with a waist circumference of $120 \mathrm{~cm}$ and blood pressure of 110/70. Various laboratory tests were performed when the patient started treatment in our clinic. As listed in Table 1, the results were compared to those obtained before using paliperidone. It is evident from Table 1 that 3 year use of paliperidone dramatically increased fasting blood sugar, total cholesterol, low-density lipoprotein, triglycerides and prolactin levels in the patient. These findings reflect one of the side effects of antipsychotic drugs, namely, metabolic syndrome. Hence, it was planned that the drug treatment would be gradually phased out in 3 weeks to prevent further increases in these metabolic parameters. The same laboratory tests were repeated 1 week after the patient completely stopped using the medication, the results of which are also listed in Table 1 in addition to the previous measurements, which enables clear identification of the side effects of paliperidone. As shown in Table 1, the metabolic parameters of the patient decreased into the normal range once the medication was stopped. There was also no changes in behaviour, increase in complaints, and side effects as compared to the period when the drug was used. As a consequence, it was decided that the patient should be followed without using any medication.

\section{KAYNAKLAR}

1. Almandil NB, Wong IC. Review on the current use of antipsychotic drugs in children and adolescents. Archives of Disease in Childhood-Education \& Practice Edition, 2011; 96(5):192-196.

2. Clarke WP, Chavera TA, Silva M, Sullivan LC, Berg KA. Signalling profile differences: paliperidone versus risperidone. British Journal of Pharmacology, 2013; 170(3):532-545.

3. Fàbrega M, Sugranyes G, Baeza I. Two cases of long-acting paliperidone in adolescence. Therapeutic Advances in Psychopharmacology, 2015; 5(5):304-306.

\section{Discussion}

Sliwa et al. (3) conducted various studies on the use of paliperidone and its metabolic side effects during adulthood. However, insufficient information is available regarding the efficacy/usefulness and safety of paliperidone for patients $<18$ years of age (4). Paliperidone should be used carefully based on the side effects seen when patients use atypical antipsychotics as well as when these drugs are used in children and adolescents, and patients should be evaluated during clinical use. Future work needs to be performed in this regard.

Yazışma adresi: Dr. Meltem İnci Kefal, Manisa Celal Bayar Üniversitesi Tıp Fakültesi Çocuk ve Ergen Ruh Sağlı̆ğ A.D., Manisa meltemincikefal@hotmail.com
4. Sliwa JK, Fu DJ, Bossie CA, Turkoz I, Alphs L. Body mass index and metabolic parameters in patients with schizophrenia during long-term treatment with paliperidone palmitate. BMC Psychiatry, 2014; 14(1):52. 